\title{
THE FORMATION OF MEDIAL MORAINES ON ALPINE GLACIERS
}

\author{
By R. J. Small, M. J. Glark, and T. J. P. Cawse \\ (Department of Geography, University of Southampton, Southampton $\mathrm{SO}_{9}{ }_{5} \mathrm{NH}$, England)
}

\begin{abstract}
Aвstract. Field investigation of six medial moraines on glaciers near Arolla, Valais, Switzerland, has revealed that all are nourished by englacial till. This is probably derived from supraglacial point-sources on the accumulation zones of the glaciers, and is released in increasing quantities on the ablation zones, where it emerges diffusely or by way of clearly defined transverse or longitudinal debris bands. Possible mechanisms of formation of these debris bands are reviewed, and it is proposed that the transverse bands originated as crevasse fillings on the accumulation zones. Morphologically all six moraines display waxing sections (of increasing height and breadth), related to development of a protective till cover and resultant differential ablation of the glacier surface. Two only display waning sections (of decreasing height), resulting from lateral sliding of till and "inverted" differential ablation resulting from extreme attenuation of till cover. Four "moraine-types" (related to nature of debris supply and detailed morphology) are identified in the Arolla area. It is believed that these may form the basis for a classification of medial moraines.
\end{abstract}

RÉsumé. La formation des moraines médianes des glaciers alpins. Des recherches sur six moraines médianes de glaciers près d'Arolla, Valais, Suisse, ont révélé qu'elles sont toutes nourries par la moraine interne. Les matériaux proviennent probablement de points-sources émergeant hors de la glace dans la zone d'accumulation des glaciers, et sont restitués en quantités croissantes dans les zones d'ablation où ils émergent soit de manière diffuse soit sous forme de rubans de sédiments clairement visibles, transversaux ou longitudinaux. Les mécanismes possibles de formation de ces rubans sont passés en revue et on propose pour origine des rubans transversaux, le remplissage de crevasses dans la zone d'accumulation. Morphologiquement, toutes les six moraines montrent des sections croissantes (en hauteur et en largeur), en raison de la création d'une couche protectrice de matériaux morainiques et de l'ablation différentielle de la surface du glacier. Deux sections seulement vont en s'évanouissant (hauteur décroissante) en raison du glissement latéral de la moraine et de l'ablation différentielle "inverse" causée par l'amincissement extrême de la couverture de matériaux morainiques. Quatre "types de moraines" (distingués d'après la nature de leurs matériaux et le détail de leur morphologie) sont identifiés dans le secteur d'Arolla. On pense que ces types de moraines peuvent former la base pour une classification des moraines médianes.

Zusammenfassung. Die Bildung von Mittelmoränen auf Alpengletschern. Felduntersuchungen an 6 Mittelmoränen auf Gletschern bei Arolla im Wallis, Schweiz, haben ergeben, dass alle durch Schutt aus dem Inneren der Gletscher ernährt werden. Dieser stammt vermutlich von punktuellen Quellen oberhalb der Gletscher und taucht in zunehmendem Masse in den Ablationszonen auf, wo er unregelmässig austritt oder klar erkennbare Bänder in Quer- oder Längsrichtung bildet. Es werden mögliche Mechanismen für die Entstehung dieser Schuttbänder betrachtet; dabei lässt sich vermuten, dass die Querbänder aus Spaltenfüllungen in den Akkumulationszonen stammen. Morphologisch lassen alle 6 Moränen Zuwachsgebiete (mit anwachsender Höhe und Breite) erkennen, die mit der Entwicklung eines schützenden Schuttmantels und der dadurch hervorgerufenen differentiellen Ablation der Gletscheroberfläche in Beziehung stehen. Nur 2 zeigen Abnahmebereiche (mit verminderter Höhe) als Folge seitlichen Gleitens von Schutt und "umgekehrter" differentieller Ablation wegen der extremen Ausdünnung des Schuttmantels. Im Arolla-Gebiet lassen sich 4 Moränentypen (in Abhängigkeit von der Art des Schuttnachschubs und von der detaillierten Morphologie) feststellen. Es wird angenommen, dass dies die Grundlage für eine Klassifizierung der Mittel-
moränen bilden kann.

\section{INTRODUCTION}

Medial moraines, comprising longitudinal ice-cored ridges up to $20 \mathrm{~m}$ or more in height and veneered by till ranging from a few centimetres to $0.5 \mathrm{~m}$ in thickness, are characteristic features of many Alpine glaciers. However, study of the detailed morphology of these moraines has been limited. The present investigation, carried out during 1976 and 1977 , has entailed field survey of medial moraines on three glaciers at Arolla, Valais, Switzerland. The two moraines of the lower Glacier de Tsidjiore Nouve (Fig. I), each about I km long, have previously been described (Small and Clark, 1974). Bas Glacier d'Arolla (Fig. 2), similar to that of Tsidjiore Nouve in being fed by a massive ice fall, also possesses two medial moraines, though these are very much shorter. Haut Glacier d'Arolla (Fig. 3), which in contrast to the other glaciers has an even gradient from source to snout, again bears two moraines, that to the west extending for nearly $3 \mathrm{~km}$. Within the study area there is thus a range of moraine dimensions. Surveyed cross-profiles at frequent intervals, providing the data summarized in Tables II and III, indicate that considerable variability of morphology also exists. 

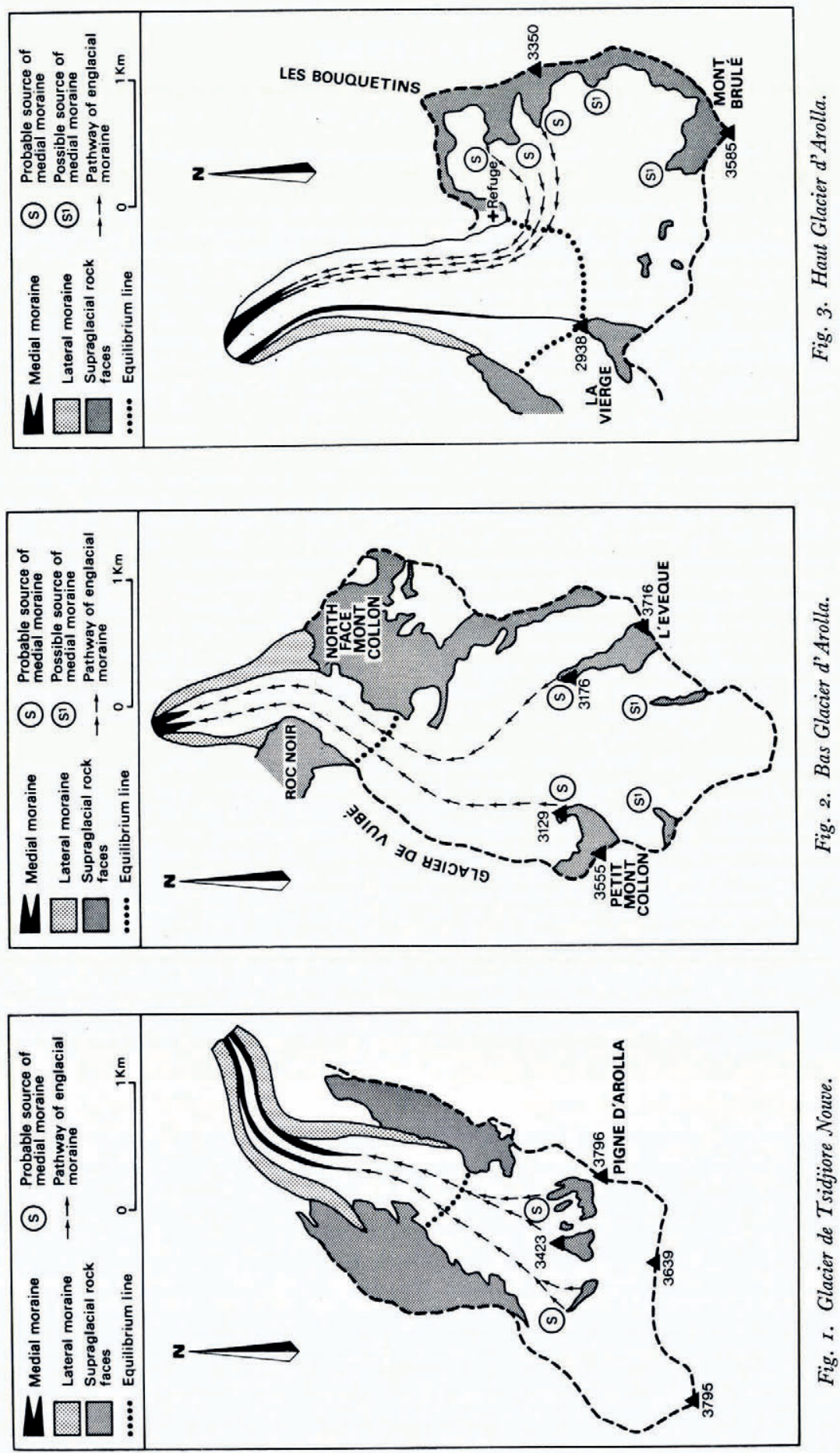


\section{LiterATURE REVIEW}

Medial moraines are usually attributed to the uniting of tributary ice-tongues, with associated lateral moraines, to form a trunk glacier (Sharp, 1948). Where the lateral moraine debris is derived directly from gelifraction of supraglacial rock faces, the medial moraine will initially comprise a layer of angular till resting on the ice surface. Differential ablation downglacier will gradually develop a prominent ice-cored ridge. However, it is likely that some debris will penetrate the margins of the tributary glaciers, either between ice and valley wall or via marginal crevasses; this may in turn be supplemented by material derived from lateral glacial erosion. Beneath the surface till of the medial moraine there may thus develop a narrow and increasingly compressed zone of debris-charged ice, the "longitudinal septum" of Sharp ( 1949), formed by the amalgamation of marginal till bands. This till will be released by surface melting on the ablation zone of the trunk glacier.

The wide applicability of this explanation of medial moraine formation is readily observable. However, at first sight it offers no adequate explanation of those moraines which "emerge" from glaciers in positions that bear no evident relationship to tributary glacier junctions. Moreover, development of the hypothesis is needed to account for variability of moraine morphology. In this last context, preliminary observations have been made by Loomis (1970), whose study of the large medial moraine of Kaskawulsh Glacier, Yukon, revealed systematic variations in cross-sectional form down-glacier from the moraine origin. "At the head of the moraine the relief is low (less than $2 \mathrm{~m}$ ). Down-glacier the relief increases until it reaches a maximum of $20 \mathrm{~m}$ at a distance of $\mathrm{I} .4 \mathrm{~km}$. The relief subsequently decreases to a height of $7 \mathrm{~m}$ at $5 \mathrm{~km}$ below the confluence. The moraine then maintains this relief magnitude for several kilometres towards the terminus". In brief, Loomis identifies what we may conveniently refer to as "waxing", "waning", and "constant" stages of moraine development. The waxing stage is attributed mainly to the insulating effect of the till cover (Østrem, 1959), resulting in differential ablation of protected and bare ice. The waning stage is related to subsequent attenuation of the till cover by lateral sliding and extending glacier flow. The effectiveness of the till as an insulator is thereby reduced, though Loomis states that it is still sufficient to retard ice-core ablation rates relative to uncovered ice. Finally, he refers to an "equilibrium state" that causes moraine relief thereafter to remain unchanged, though the factors involved in this equilibrium need to be clarified.

Two of the present authors (Small and Clark, 1974) have also identified waxing and waning stages on the "emergent" medial moraines of the lower Glacier de Tsidjiore Nouve. The waxing stage is again related to increasingly effective differential ablation, as debris initially of supraglacial origin and contained within the uppermost $100 \mathrm{~m}$ of the glacier is gradually released. The waning stage is attributed to (a) exhaustion of the englacial debris source by progressive down-glacier ablation, and (b) sliding of released till over lateral slopes of up to $29^{\circ}$. The resultant attenuation of the till cover, to an average thickness of about $\mathrm{I} \mathrm{cm}$, is believed to induce ablation at a rate in excess of that of nearby bare ice, and hence decline of the moraine as a relief feature. Detailed observations of ablation rates in 1976 offer strong confirmation of the suggested relationship (Table I).

More recently, it has been proposed that although differential ablation and lateral till sliding may be principal determinants of moraine morphology, other factors need to be considered. The complex interrelationships involved in moraine development are summarized in a systems diagram (Small and Clark, I976) which emphasizes (a) the causal links between debris supply, thickness of till cover, differential ablation $(D a)$ (expressed as the ratio of clean ice ablation to covered ice ablation, normally $>$ I.o), and increasing moraine relief, (b) the positive relationships between moraine height, debris sliding and moraine width, and (c) a negative feedback relationship, whereby attenuation of till to a critical thinness $(c . \mathrm{I} \mathrm{cm})$ produces a $(D a)$ value of $<\mathrm{I} . \mathrm{O}$ and moraine decline. 
Table I. Ablation transect of Glacier de Tsidjiore Nouve (24 July 1976 to 2 SePtember 1976 )

Transect across peak of main medial moraine and waning section of subsidiary moraine.

Site

S. face main moraine Crest of main moraine $\mathrm{N}$. face main moraine Clean ice

S. face subsidiary moraine

N. face subsidiary moraine Clean ice

$\begin{array}{cc}\begin{array}{c}\text { Till } \\ \text { thickness } \\ \mathrm{cm}\end{array} & \begin{array}{c}\text { Total } \\ \text { ablation } \\ \mathrm{cm}\end{array} \\ 6 & 64.3 \\ 5 & 52.8 \\ 6 & 67.4 \\ - & 142.4 \\ 2 & 169.9 \\ 1 & 161.1 \\ - & 141.0\end{array}$

Days of
observation

39
39
32
36
39
35
36

\section{Medial moraines of the Arolla area}

\section{(I) Additional observations of Glacier de Tsidjiore Nouve}

In this study attention has been focused on the problem of debris feed to the medial moraine. Formerly it had been suggested (Small and Clark, 1974) that the beaded form of these moraines in their emergent sections reflected the concentration of till within the broad dark-ice ogives at the base of the Pigne d'Arolla ice fall. This association has been questioned by Eyles (1976), who on the basis of observations on Austerdalsbreen explained the association between transverse debris covered ridges and dark ogives in terms of an initial lowering of the latter by rapid ablation (an albedo effect), producing transverse troughs within which randomly distributed surficial till will accumulate. In time these concentrations of debris will be sufficiently protective to give "relief inversion" by way of normal differential ablation.

Our observations now reveal that the links between transverse ridges and dark ogives are in fact tenuous; several ice-cored mounds are developed on white-ice ogives. Moreover, clearance of surface till from ridges at the head of the main moraine shows that each is nourished from below by one or more well-defined transverse bands of debris within the ice. The dimensions of individual ridges are in fact closely determined by (a) the thickness and debris concentration of the bands, and (b) the lateral extent of the bands (often no more than a few metres). Similar structures were found to cross the crest line of the main moraine $300 \mathrm{~m}$ down-glacier, and it is estimated that the medial moraine as a whole is fed by upwards of 100 individual debris bands.

In detail, the bands range from $5^{-20} \mathrm{~cm}$ in thickness, and dip up-glacier at $70-80^{\circ}$. Sometimes they comprise a high concentration of grit and stones, invariably angular or sub-angular, showing a rude stratification. The structure of the bands may be composite, with streaks of dark bubble-free ice interdigitating with seams of frozen silt and sand. Occasionally large slabby boulders, up to $0.5 \mathrm{~m}$ along the $a$ axis, produce localized broadenings of the debris bands. A typical resultant transverse mound is that at the very head of the Tsidjiore Nouve main moraine. This reaches a maximum height of $2.4 \mathrm{~m}$, a width across the glacier of $26 \mathrm{~m}$, and a length of $33 \mathrm{~m}$, and is fed by one major and one minor debris band. In general form this ridge resembles a small-scale version of the "shear moraines" described by Boulton (1967) or the "hummocky moraine" referred to by Souchez ( 1967 ).

\section{(2) The medial moraines of Bas Glacier d'Arolla}

The lower tongue of this glacier supports two very small medial moraines which emerge close to the snout (Fig. 2).

(i) The eastern moraine begins as a patchy cover of boulders and stones, which merge down-glacier to give a continuous till layer. The moraine then grows quite rapidly into a prominent ridge (Table IIa), standing 6-8 $\mathrm{m}$ above the adjacent bare ice. Close to the snout 
Table II. The morphology of the medial moraines, Bas Glacier d'Arolla

\begin{tabular}{|c|c|c|c|c|c|}
\hline Profile & $\begin{array}{c}\text { Distance } \\
\text { from } \\
\text { head } \\
\mathrm{m}\end{array}$ & $\begin{array}{l}\text { Number } \\
\text { of } \\
\text { ridges }\end{array}$ & $\begin{array}{c}\text { Maximum } \\
\text { height } \\
\mathrm{m}\end{array}$ & $\begin{array}{l}\text { Maximum } \\
\text { width } \\
\mathrm{m}\end{array}$ & $\begin{array}{c}\text { Maximum slope } \\
\text { angle and } \\
\text { orientation }\end{array}$ \\
\hline
\end{tabular}

$\begin{array}{rr}\text { A } & 20 \\ \text { B } & 40 \\ \text { C } & 60 \\ \text { D } & 80 \\ \text { E } & 100 \\ \text { F } & 120 \\ \text { G } & 140 \\ \text { H } & 160\end{array}$

(a) The eastern moraine

$\begin{array}{rr}\text { A } & 20 \\ \text { B } & 40 \\ \text { C } & 60 \\ \text { D } & 80 \\ \text { E } & 100 \\ \text { F } & 120 \\ \text { G } & 140 \\ \text { H } & 160\end{array}$

$\begin{array}{ll}\text { r.5 } & 31 \\ 4.0 & 32 \\ 6.5 & 44 \\ 8.0 & 42.5 \\ 7.5 & 48.5 \\ 6.0 & 33.5 \\ 6.5 & 35.5 \\ 3.5 & 30\end{array}$

$$
\begin{aligned}
& 13^{\circ} \mathrm{E} . \\
& 19^{\circ} \mathrm{E} . \\
& 32^{\circ} \mathrm{E} . \\
& 31^{\circ} \mathrm{E} . \\
& 29^{\circ} \mathrm{E} . \\
& 21^{\circ} \mathrm{E} . \\
& 22^{\circ} \mathrm{E} . \\
& 21^{\circ} \mathrm{E} .
\end{aligned}
$$

(b) The western moraine

$\begin{array}{lll}6 & 18 & 33^{\circ} \mathrm{W} . \\ 9 & 32.5 & 30^{\circ} \mathrm{W} . \\ 13.5 & 39 & 34^{\circ} \mathrm{E} . \\ \mathrm{I} 4.5 & 50 & 41^{\circ} \mathrm{W} . \\ 16 & 54 & 36^{\circ} \mathrm{W} . \\ 12 & 51.5 & 31^{\circ} \mathrm{W} . \\ 15.5 & 54.5 & 33^{\circ} \mathrm{W} . \\ 6.5 & 35.5 & 40^{\circ} \mathrm{E} .\end{array}$

a decline to $3-5 \mathrm{~m}$ is induced by rapid sliding of till over longitudinal slopes of $13^{-1} 5^{\circ}$. At no point were debris bands identifiable in the underlying glacier; evidently englacial till is diffused through a considerable thickness of ice.

(ii) The western moraine also begins as a line of patchy superficial till, extending downglacier for $75 \mathrm{~m}$, beyond which point the ridge grows rapidly. A maximum height of $14-16 \mathrm{~m}$ is attained, though there is again decline immediately above the snout (Table IIb). Nourishment by individual transverse debris bands (as on Glacier de Tsidjiore Nouve) can be readily observed. In all 28 individual bands were identified in the "zone of emergence", varying in lateral extent from $\mathrm{I} \mathrm{m}$ to a maximum of $\mathrm{i} \mathrm{I} \mathrm{m}$. Spacing varied, but tended to increase down-glacier, 20 bands occurring within $30 \mathrm{~m}$ before the commencement of the ridge proper. In general structure the debris bands of Bas Glacier resembled those of Glacier de Tsidjiore Nouve, though they are less rich particularly in finer debris. The till released by ablation was insufficient to give the beaded form, except in the most subdued and rudimentary fashion.

\section{(3) The medial moraines of Haut Glacier d'Arolla}

The two moraines of Haut Glacier show important contrasts of scale and morphology (Fig. 3).

(i) The western moraine, commencing at the base of La Vierge on the equilibrium line of the glacier, extends for over $2.6 \mathrm{~km}$ to the glacier snout. It appears to be supplied by falls of debris from the flanks of La Vierge directly onto the glacier surface. However, clearance of till from the moraine crest has revealed longitudinal debris bands, as little as $6-8 \mathrm{~cm}$ wide and comprising dark bubble-free ice with silt, sand, grit, and small angular stones. The overall contribution to the till cover made by this miniature septum seems small. The morphological development of the western moraine is summarized in Table IIIa. Although fluctuating somewhat, height and width generally increase towards the snout, reaching I I $\mathrm{m}$ and $60.5 \mathrm{~m}$ on the final surveyed profile. Despite its considerable length this moraine remains a small feature, reflecting a limited initial supraglacial debris input and a small englacial feed. 
(ii) The eastern moraine is a complex and ultimately more prominent feature than the western moraine. Debris begins to appear at the glacier surface only $\mathrm{I} \mathrm{km}$ from the snout, forming initially small but well-defined parallel ridges aligned north-south. These merge down-glacier to give a single large ridge, reaching a height of $15^{-1} 8 \mathrm{~m}$ and a width of nearly I $00 \mathrm{~m}$ (Table IIIb). The most notable feature is the emergence of till not from the usual transverse bands, but from longitudinal planes dipping steeply westwards towards the centre line of the glacier. Within these planes are large concentrations of coarse debris, including numbers of slabby boulders up to $\mathrm{I} \mathrm{m}$ or more along the $a$ axis.

Table III. The morphology of the medial moraines, Haut Glacier d'Arolla

$\begin{array}{ccc}\text { Profile } & \begin{array}{c}\text { Distance } \\ \text { from } \\ \text { source } \\ \mathrm{m}\end{array} & \text { Numb } \\ & \\ & \\ \mathrm{A} & 200 \\ \mathrm{~B} & 400 \\ \mathrm{G} & 600 \\ \mathrm{D} & 800 \\ \mathrm{E} & 1000 \\ \mathrm{~F} & \mathrm{I} 200 \\ \mathrm{G} & \mathrm{1} 400 \\ \mathrm{H} & \mathrm{I} 600 \\ \mathrm{I} & \mathrm{I} 800 \\ \mathrm{~J} & 2000 \\ \mathrm{~K} & 2200 \\ \mathrm{~L} & 2400 \\ \mathrm{M} & 2600\end{array}$<smiles>[Mg][Mg][Mg]</smiles>

Maximum
height

$\mathrm{m}$

(a) The western moraine

$\begin{array}{cl}7 & 45 \\ 3.5 & 19.5 \\ 4.5 & 20.5 \\ 4 & 24 \\ 5 & 35 \\ 8.5 & 39 \\ 6 & 36.5 \\ 6.5 & 39.5 \\ \text { I0.5 } & 44 \\ 6.5 & 42.5 \\ \text { I0 } & 50 \\ 8.5 & 57 \\ \text { I I } & 60.5\end{array}$

(b) The eastern moraine

$\begin{array}{lll}2.25 & 14.5 & 28^{\circ} \mathrm{W} . \\ 1.8 & 17.5 & 21^{\circ} \mathrm{W} . \\ 2 & 46 & 18^{\circ} \mathrm{W} . \\ 2.5 & 49.5 & 15^{\circ} \mathrm{W} . \\ 2.5 & 38.5 & 19^{\circ} \mathrm{W} . \\ 3.5 & 51 & 25^{\circ} \mathrm{W} . \\ 8 & 62 & 30^{\circ} \mathrm{W} . \\ 7 & 62.5 & 22^{\circ} \mathrm{W} . \\ 7.5 & 63 & 31^{\circ} \mathrm{W} . \\ 8.25 & 67.5 & 24^{\circ} \mathrm{W} . \\ 9.5 & 76.5 & 32^{\circ} \mathrm{E} . \\ 13.2 & 95.5 & 26^{\circ} \mathrm{E} . \\ 17 & 93.5 & 40^{\circ} \mathrm{E} . \\ 15 & 88.5 & 32^{\circ} \mathrm{W} . \\ 17.75 & 95.5 & 32^{\circ} \mathrm{W} . \\ 15.5 & 77 \text { (incomplete) } & 32^{\circ} \mathrm{W} .\end{array}$

\section{Maximum slope angle and orientation}

1
1
2
2
2
1
1
2
2
2
3
2
1
1
1
1

$\begin{array}{lr}\text { A } & \\ \text { B } & 60 \\ \text { C } & 120 \\ \text { D } & 180 \\ \text { E } & 240 \\ \text { F } & 300 \\ \text { G } & 360 \\ \text { H } & 420 \\ \text { I } & 480 \\ \text { J } & 540 \\ \text { K } & 600 \\ \text { L } & 660 \\ \text { M } & 720 \\ \text { N } & 780 \\ \text { O } & 840 \\ \text { P } & 900\end{array}$

THE ORIGIN OF DEBRIS BANDS WITHIN ALPINE GLAGIERS

As summarized by Boulton ( 1967$)$, there are four ways in which debris bands within glaciers are formed:

(a) They may have accumulated in former crevasses, now closed by glacier movement.

(b) They may represent surface sedimentary layers, dominantly of supraglacial material, developed and incorporated on the accumulation zone.

(c) They may derive from subglacial till frozen onto the glacier base and raised towards the surface as flow-lines turn upwards near the frontal margins (Weertman, I96I). However, this explanation is inappropriate to temperate Alpine glaciers.

(d) They may comprise subglacial till dragged up along shear planes in the ice. From his study of emergent debris bands and associated ice-cored ridges, Boulton infers that the 
last-named process has operated close to the snout of Sørbreen, Vestspitsbergen. However, the observed bands are frequently of considerable lateral extent (up to $275 \mathrm{~m}$ ), and are up to I $\mathrm{m}$ in thickness; moreover included pebbles are mainly well rounded. There are thus important differences between the Sørbre and Arolla bands. It is well known that in zones of strong ice compression (as at the base of ice falls), there is a tendency towards up-shearing, as evidenced by the occurrence of steeply dipping transverse foliation (Taylor, 1963; Rutter, 1965). However, on Glacier de Tsidjiore Nouve, shearing in this position would hardly produce planes extending laterally for only a few metres, nor could it account for the strong localization of englacial debris, unless the latter had been raised along shears initiated at the glacier bed at a depth of $200 \mathrm{~m}$ - an unlikely mechanism. For this reason, and others, we reject the shearing hypothesis to account for englacial debris bands feeding Alpine medial moraines.

Alpine glaciers undoubtedly derive a large proportion of their englacial till content from summer accumulation of debris, which is incorporated as a succession of seasonal layers on the accumulation zone. It is likely that in most instances these debris layers will be limited in lateral extent, especially where developed beneath small rock faces between convergent ice streams. Moreover, subsequent lateral ice compression will further restrict the width of the till zone, converting it into a longitudinal septum. Additionally, if the site of debris entrainment is high up on the accumulation zone, the debris layers will be buried beneath superincumbent clean ice formed lower on the accumulation zone. Exposure of such debris by ablation will necessarily occur well below the equilibrium line, even quite close to the glacier snout. Study of the ogive suites of Glaciers de Tsidjiore Nouve and Bas Arolla suggest that they have occupation cycles of between 50 and roo years. Thus the debris which eventually emerges to form the medial moraines must be inert within the ice for several decades.

Nevertheless, it cannot be assumed that transverse debris bands are former surface accumulations. The prevailing steep dips (usually greater than $70^{\circ}$ up-glacier) suggest the possibility that many are exposed crevasse infillings. We may visualize that the original live crevasses were developed adjacent to rock faces high above the accumulation zone, where they could ingest debris either directly from gravity fall or via surface melt-water transport. Subsequently these crevasses would be (a) closed and buried beneath clean ice, (b) subjected to lateral and longitudinal compression, and (c) exposed on the ablation zone to form beaded moraines.

Obviously the longitudinal debris bands, particularly of the eastern moraine of Haut Glacier d'Arolla, pose a separate problem. Possibly they were developed as highly compressed septa, which were subsequently modified by shearing between ice-streams of differing velocities. As Weertman (I96I) points out, a pre-existing debris layer may be subjected to a shear component such as is always found in glaciers. "If the debris layer has the property that discrete shear takes place within it when ... . a stress is applied, this shear will occur regardless of how the debris layer was formed originally". We propose the hypothesis that the debris layers of Haut Glacier are inherited from the accumulation zone, the eastern part of which forms a broad ice-field extending eastwards from La Vierge (Fig. 3). Down-glacier this eastern ice-tongue is rapidly reduced to a width of $1.1 \mathrm{~km}$ between La Vierge and the Bouquetins Refuge, and then to only $0.4 \mathrm{~km}$ where the eastern moraine emerges. This substantial lateral compression would greatly reduce the width of debris bands within the ice, particularly if in the first instance these were derived from point-sources (e.g. strongly weathered rock faces of limited lateral extent) on the western cliffs of the Bouquetins.

\section{TyPes OF MEDiAL MORAINE}

The medial moraines of the Arolla area show considerable differences of morphology which doubtless reflect the complex interactions depicted by the systems diagram (Small and Clark, I976). In ideal circumstances, medial moraines contain waxing and waning sections, 


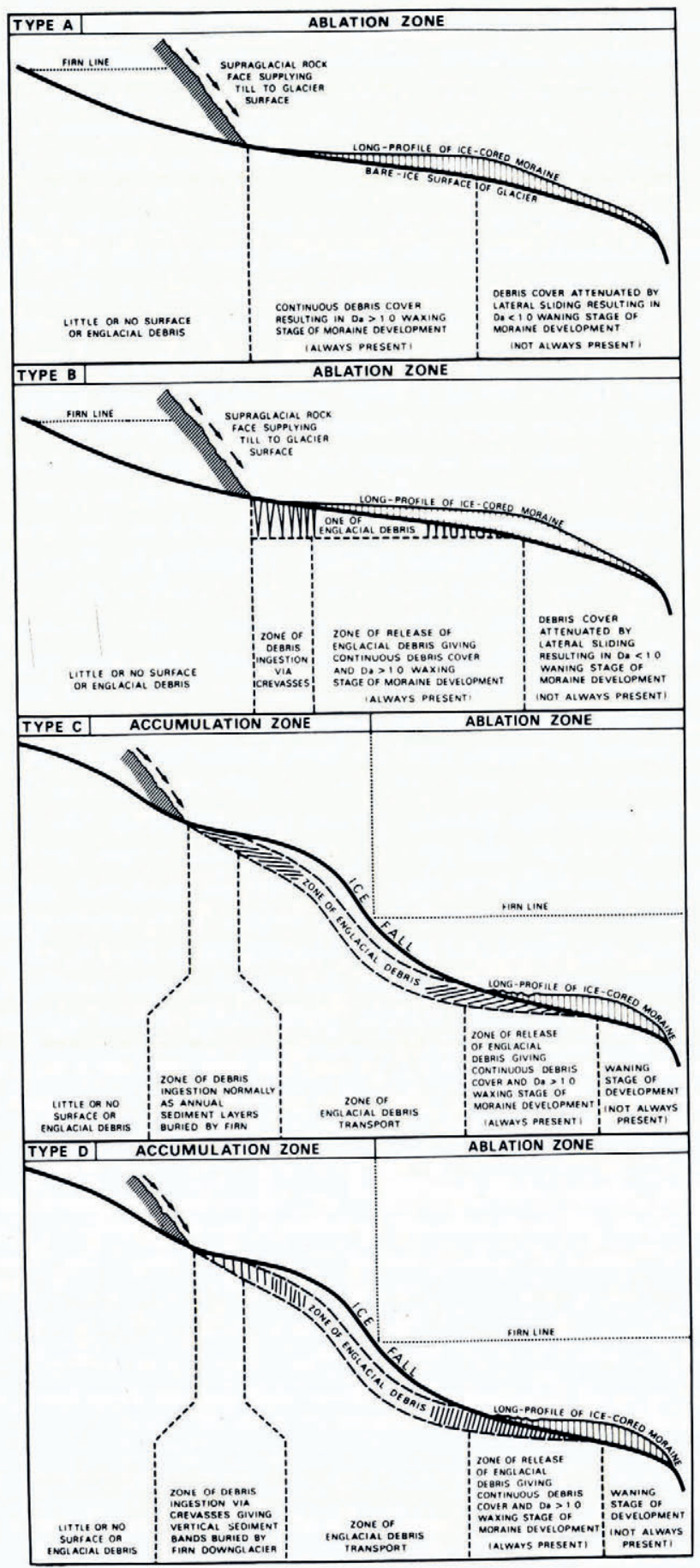

Fig. 4. Types of medial moraine. 
to which might be added a constant section (Loomis, 1970). The failure of four of the Arolla moraines even to approach "full development" probably depends on three factors, all related to debris supply.

(a) Volume of debris. If this is considerable, differential ablation will give a sequence of rapid moraine growth, rapid lateral sliding of debris, attenuated till cover, accelerated ablation, and moraine decline. If debris supply is insubstantial, differential ablation will be less marked and the stage of moraine growth protracted.

(b) The balance between direct supraglacial and indirect englacial debris supply. If the moraine is nourished by debris falls within the ablation zone, it will grow at a rate commensurate with debris amounts. If, however, it is supplied by falls in the accumulation zone, till will be ingested. This will eventually melt out slowly, in such a way that the waxing stage is again extended.

(c) The length of the glacier. This is important in the sense that, ceteris paribus, the longer the glacier the greater the opportunity for full moraine development. However, even on long glaciers the precise point at which till accumulates in sufficient quantities on the ice surface is critical.

In the light of this investigation, the following types of medial moraine are proposed (Fig. 4).

Type A. This moraine is fed by supraglacial sources close to or below the equilibrium line. It grows in height from source, and if the total debris supply is sufficient, a waning section will be initiated down-glacier. The western moraine of Haut Glacier is of this type, except that (i) there is some englacial feed, and (ii) the debris cover supports only the waxing stage.

Type B. This is a variant of type A, developed where crevasses allow till ingestion rather than surface accumulation alone. The melting-out of the englacial debris (confined to the upper $30 \mathrm{~m}$ of the ice) will result in extension of the waxing section.

Type $C$. This moraine is fed by falls of rock onto the ice surface well above the equilibrium line. Debris is incorporated as a series of annual layers, which are buried beneath ice formed lower on the accumulation zone. On the ablation zone, this englacial till will melt out to give a relatively short moraine. Only if the debris content is large and concentrated will there be development beyond the waxing stage. The eastern moraines of Bas and Haut Glaciers d'Arolla fall broadly into this category.

Type $D$. This moraine is also fed above the equilibrium line, but in this instance till incorporation is by way of marginal crevasses. Eventually the resultant steep debris bands melt out to form beaded moraines (as on Glacier de Tsidjiore Nouve). Whether such moraines develop beyond the waxing stage depends on (i) total debris, (ii) the precise point of emergence on the glacier tongue. On Glacier de Tsidjiore Nouve both factors are favourable; on the western moraine of Bas Glacier they are not.

Note that in depicting types $\mathrm{C}$ and D moraines, Figure ${ }_{4} \mathrm{C}$ and D have been drawn to include an ice fall to emphasize applicability to both these glaciers.

It is realized that, in proposing these moraine types after field study of three glaciers only, we are not erecting a comprehensive classification of medial moraines. Nevertheless, it is worth recording that a reconnaissance survey of other Swiss glaciers (including Gornergletscher and Glacier de Cheilon) has revealed replication of the four types, but as yet no others.

\section{Acknowledgement}

Drs Small and Clark wish to record their thanks to the University of Southampton, which provided a grant to assist the completion of the study in the field.

MS. received 16 . January 1978 and in revised form 19 April 1978 


\section{REFERENCES}

Boulton, G. S, 1967 . The development of a complex supraglacial moraine at the margin of Sørbreen, Ny Friesland, Vestspitsbergen. Journal of Glaciology, Vol. 6, No. 47, p. 71 7-35.

Boulton, G. S. 1970. On the origin and transport of englacial debris in Svalbard glaciers. Fournal of Glaciology, Vol. 9, No. 56, p. $213-29$.

Eyles, N. 1976. Morphology and development of medial moraines: comments on the paper by R. J. Small and M. J. Clark. Journal of Glaciology, Vol. 17, No. 75, p. 161-62. [Letter. Further comments, p. 164-65.]

Loomis, S. R. 1970. Morphology and ablation processes on glacier ice. (In Bushnell, V. C., and Ragle, R. H., ed. Icefield Ranges Research Project. Scientific results. Vol. 2. New York, American Geographical Society; Montreal, Arctic Institute of North America, p. 27-31.)

Østrem, G. I959. Ice melting under a thin layer of moraine, and the existence of ice cores in moraine ridges. Geografiska Annaler, Vol. 41, No. 4, p. 228-30.

Rutter, N. W. rg65. Foliation pattern of Gulkana Glacier, Alaska Range, Alaska. Journal of Glaciology, Vol. 5, No. 41, p. 711-18.

Sharp, R. P. 1948. The constitution of valley glaciers. Fournal of Glaciology, Vol. 1, No. 4, p. 174-75, 182-89.

Sharp, R. P. 1949. Studies of superglacial debris on valley glaciers. American Journal of Science, Vol. 247, No. 5 ,

p. ${ }^{289}-3{ }^{15}$.
Small, R. J., and Clark, M. J. r974. The medial moraines of the lower Glacier de Tsidjiore Nouve, Valais, Switzerland. Fournal of Glaciology, Vol. 13, No. 68, p. 255-63.

Small, R. J., and Clark, M. J. 1976. Morphology and development of medial moraines: reply to comments by N. Eyles. Journal of Glaciology, Vol. 1 7, No. 75, p. 162-64. [Letter. Reply to further comments, p. 165.]

Souchez, R. A. r 967 . The formation of shear moraines: an example from south Victoria Land, Antarctica.

Journal of Glaciology, Vol. 6, No. 48, p. $837-43$.
Souchez, R. A. 1971. Ice-cored moraines in south-western Ellesmere Island, N.W.T., Canada. Fournal of Glaciology, Vol. 10, No. 59, p. 245-54.

Taylor, L. D. 1963. Structure and fabric on the Burroughs Glacier, south-east Alaska. Journal of Glaciology, Vol. 4 , No. 36 , p. $731-52$.

Weertman, J. 1961. Mechanism for the formation of inner moraines found near the edge of cold ice caps and ice sheets. Journal of Glaciology, Vol. 3 , No. 3o, p. $965-78$. 